\author{
Антонюк О.П. \\ кандидат економічних наук, доцент \\ кафедра обліку та аудиту \\ Одеська національна академія харчових технологій \\ вул. Канатна, 112, м. Одеса, Україна, 65039 \\ E-mail: olegantoni@ukr.net \\ Антонюк П.О. \\ кандидат економічних наук, науковий співробітник \\ E-mail: paul antonyuk@ukr.net \\ Лисюк В.М. \\ доктор економічних наук, професор \\ відділ ринкових механізмів і структур \\ Інститут проблем ринку та економіко-екологічних досліджень НАН України \\ Французький бульвар, 29, м. Одеса, Україна, 65044 \\ E-mail: vlisyuk@ukr.net
}

\title{
АНАЛІЗ ДИНАМІКИ ТА СТРУКТУРИ ЕКСПОРТУ АГРОПРОДОВОЛЬЧОї ПРОДУКЦІї
}

У статті досліджено питання товарної та географічної структури експорту агропродовольчих товарів, які останніми роками становляться головними в загальному експорті. Розглянуто основні напрями експортних потоків агропродовольчих товарів в розрізі чотирьох товарних груп, їх динаміку а також можливості змін для зростання обсягів експорту.

Ключові слова: агропродовольча продукція, готові продукти харчування, товарна структура експорту, географія експортних потоків, диверсифікація експорту, експортна виручка.

This work is licensed under a Creative Commons Attribution 4.0 International License http://creativecommons.org/licenses/by/4.0/

Постановка проблеми та її зв'язок з важливими науковими та практичними завданнями. Продукти харчування та сировина для їх виробництва являються важливою складовою в міжнародній торгівлі. Україні вкрай необхідні стійке економічне зростання та підвищення життєвого рівня населення і досягти цього можливо також шляхом інтеграції в світові ринки товарів та послуг, в тому числі ринок агропродовольчої продукції. Сучасний етап розвитку економіки України в системі світових господарських зв'язків відбувається в досить складних умовах як внутрішнього так i, особливо, зовнішнього характеру. Незважаючи на значний виробничий та експортний потенціал в останні роки спостерігається певне скорочення експорту, порівняно з 2013 р., залишається обмеженою номенклатура експортної продукції, що користується значним попитом на світовому ринку, втрачаються ринки збуту тощо, що негативно впливає на економічний стан держави. Тому подолання негативних явищ в агропродовольчому експорті країни в умовах його глобалізації $\epsilon$ актуальною проблемою $\mathrm{i}$ потребує свого дослідження.

Аналіз останніх публікацій по проблемі. Дослідження проблем експорту агропродовольчої продукції знайшли відображення в працях науковців та економістів-практиків: Н.С. Голомші, Н.А. Карасьової, С.М. Кваші, Г. Квітки, М.А. Лисака, О. Маслака, I.В. Чехова, О.М. Шпичака та ін. Аналіз остан - ніх досліджень та публікацій вказує на те, що поза увагою науковців залишаються особливості товарної та географічної структури експорту окремих видів агропродовольчої продукції, що можуть являти основу для розробки експортної стратегії агропродовольчого комплексу.

Формулювання цілей дослідження. Метою даного дослідження є вивчення структури експортних потоків агропродовольчої продукції та визначення можливостей підвищення ефективності експортної діяльності.

Виклад основних результатів та їх обгрунтування. Кризові процеси в економіці України, що посилились останніми роками, негативно впливають на стан зовнішньої торгівлі, в тому числі на експорт товарів та його структуру. Починаючи з 2013 р. експорт товарів поступово скорочувався 3 62,3 млрд. дол. США в цьому році до 36,4 млрд. дол. США в 2016 р., тобто на 41,6 \%. Значно швидше скорочувався імпорт - 48,2 \%, в результаті чого від'ємне сальдо зовнішньої торгівлі товарами скоротилось 313529 млн. дол. в 2013 р. до 2886 млн. дол. в 2016 р.

До числа експортних товарів, по яких за період 2013-2016 рр. мало місце найменше скорочення відноситься агропродовольча продукція. Якщо в цілому експорт товарів скоротився на 41,6 \%, то по групі агропродовольчих товарів скорочення склало $9,7 \%$, а по жирах та олії тваринного або рослинного 
походження експорт зріс на 113,3 \%. Такий характер динаміки експорту в розрізі товарних груп призводить до зростання частки агропродовольчої продукції в загальному експорті з 27,2 \% в 2013 р. до 42,0 \% в 2016 р. (табл. 1).

Таблиця 1

Агропродовольча продукція в експорті України - динаміка та структура *

\begin{tabular}{|c|c|c|c|c|c|}
\hline \multirow[b]{2}{*}{ Показники } & \multicolumn{2}{|c|}{2013 p. } & \multicolumn{2}{|c|}{2016 p. } & \multirow{2}{*}{$\begin{array}{l}2016 \mathrm{p} . \\
\text { в \% до } \\
2013 \mathrm{p} .\end{array}$} \\
\hline & $\begin{array}{l}\text { млн. } \\
\text { дол. }\end{array}$ & $\%$ & $\begin{array}{l}\text { млн. } \\
\text { дол. }\end{array}$ & $\%$ & \\
\hline 1. Експорт, всього & 62306 & 100,0 & 36363 & 100,0 & 58,4 \\
\hline 2. Експорт агропродовольчої продукції & 16930 & 27,2 & 15284 & 42,0 & 90,3 \\
\hline 2.1. Експорт сільськогосподарської продукції & 9932 & 58,7 & 8870 & 58,0 & 89,3 \\
\hline 2.1.1. Живі тварини; продукти тваринного походження & 1083 & 6,4 & 775 & 5,0 & 71,6 \\
\hline 2.1.2. Продукти рослинного походження & 8849 & 52,3 & 8095 & 53,0 & 91,5 \\
\hline 2.2. Продукція харчової промисловості & 6998 & 41,3 & 6414 & 42,0 & 91,6 \\
\hline 2.2.1. Жири та олії тваринного або рослинного & & & & & \\
\hline походження & 3497 & 20,6 & 3963 & 25,9 & 113,3 \\
\hline 2.2.2. Готові харчові продукти & 3501 & 20,7 & 2451 & 16,1 & 70,0 \\
\hline
\end{tabular}

* розраховано авторами за даними Державної служби статистики України [5]

Агропродовольча продукція стає головним експортним товаром України, так як частка недорогоцінних металів та виробів 3 них, які тривалий час були основним експортним товаром, скоротилась за цей період з 28,1 \% до 22,9\%. Важливість експорту агропродовольчої продукції посилюється з огляду на активний торговий баланс держави в цьому секторі експорту. Незважаючи на щорічне скорочення експорту агропродовольчої продукції результатом торгових операцій є постійне зростаюче позитивне сальдо (млн. дол.): 2013 р. - 8891; 2014 р. - 10610; 2015 р. 11079; 2016 р. - 11394, що пояснюється скороченням імпорту по цій групі товарів з 8039 млн. дол. в 2013 р. до 3890 млн. дол., або на 51,6\%.

Дані табл. 1 свідчать, що в товарній структурі більшу частину експорту складають різні види сільськогосподарської продукції і в першу чергу продукти рослинного походження, тобто сировина 3 невеликою доданою вартістю. Серед продукції харчової промисловості найбільша частка припадає на жири та олії тваринного або рослинного походження, тобто продукт 3 відносно високою доданою вартістю, так як експортується головним чином олія нерафінована. За період 2013-2016 рр. структура експорту агропродовольчої продукції суттєво не змінилась. На фоні певного зменшення експорту доля сировинного експорту складає $58 \%$, в той час як доля експорту продукції 3 більшою доданою вартістю залишається на рівні 42 \%. Характеризуючи структуру експортних операцій, слід зазначити, що іiі основу становлять низькотехнологічна продукція, насамперед рослинництва, добуті природні копалини, а також продукція 3 низьким рівнем технологічної обробки [3]. Світова практика засвідчує, що жодна країна з сировинною орієнтацією експорту не може створити успішну економіку. Виправлення ситуації 3 агропродовольчим експортом України залежить від того, наскільки швидко будуть розвиватися переробні галузі, результатом чого може бути значне зростання експорту. Наприклад, у Франції за 2015 р. експорт агропродовольчої продукції склав 60,2 млрд. євро, в т.ч. сільськогосподарська продукція 15,7 млрд. євро (24 \%) і продукція харчової промисловості 44,5 млрд. євро (76 \%). В обсязі усього експорту на долю агропродовольчої продукції приходиться 13,5\% [8].

Товарна структура експорту агропродовольчих товарів в розрізі найменувань дає можливість оцінити наскільки широкий спектр продукції країна може пропонувати на зовнішньому ринку. В індустріально розвинених країнах цей перелік надзвичайно численний, в той час як в країнах з сировинним характером експорту він досить звужений. Так, на Україні основою експорту товарів продукції сільського господарства є пшениця, кукурудза, ячмінь, соя і ріпак, а продукція харчової промисловості представлена продуктами переробки соняшнику - олія та макуха табл. 2.

Як показують дані табл. 2 серед сільськогосподарської продукції на п'ять позицій приходиться більш як 83 \% валютної виручки. Впродовж 20132016 рр. ситуація не змінюється. Дуже незначною в структурі експорту аграрної продукції залишається частка м'яса, їстівних субпродуктів, овочів та фруктів тощо. Серед продукції харчової промисловості більше половини експорту приходиться на соняшникову олію та макуху. Динаміка показує, що експортні позиції цих двох видів не тільки не зменшуються (за рахунок зростання експорту інших товарів), але й посилюються.

Якщо в 2013 р. частка олії та макухи складала $57,7 \%$, то в 2016 р. - 69,5\%. Одночасно в товарній структурі експорту продукції харчової промисловості скорочується і без того невелика частка продуктів 3 м'яса і риби (0,2\%), продуктів переробки овочів (2,2 $\%)$, алкогольних та безалкогольних напоїв (2,5 \%). Обмежена кількість найменувань товарних позицій із значною часткою в валютній виручці свідчить про низький ступінь товарної диверсифікації експортних потоків агропродовольчої продукції, маючи на увазі, що з України експортується близько 170 найменувань товарних позицій експорту [6]. 
Таблиця 2

Основні експортні товари продукції АПК *

\begin{tabular}{|l|c|c|c|c|c|c|c|c|}
\hline \multirow{2}{*}{ Найменування продукції } & \multicolumn{9}{|c|}{ Роки } \\
\cline { 2 - 10 } & \multicolumn{2}{|c|}{2013} & \multicolumn{2}{|c|}{2014} & \multicolumn{2}{c|}{2015} & \multicolumn{2}{c|}{2016} \\
\cline { 2 - 10 } & млн. дол. & $\%$ & млн. дол. & $\%$ & млн. дол. & $\%$ & млн. дол. & $\%$ \\
\hline $\begin{array}{l}\text { 1. Сільськогосподарська } \\
\text { продукція }\end{array}$ & 9932 & 100,0 & 9751 & 100,0 & 8795 & 100,0 & 8870 & 100,0 \\
\hline Пшениця & 1885 & 19,0 & 2291 & 23,5 & 2238 & 25,4 & 2718 & 30,7 \\
\hline Ячмінь & 575 & 5,8 & 842 & 8,6 & 769 & 8,7 & 666 & 7,5 \\
\hline Кукурудза & 3870 & 39,0 & 3351 & 34,4 & 3002 & 34,1 & 2655 & 29,9 \\
\hline Соя & 740 & 7,4 & 703 & 7,2 & 805 & 9,2 & 986 & 11,1 \\
\hline Ріпак & 1197 & 12,0 & 871 & 8,9 & 570 & 6,5 & 392 & 4,4 \\
\hline Інші & 1665 & 16,8 & 1693 & 17,4 & 1411 & 16,0 & 1453 & 16,4 \\
\hline $\begin{array}{l}\text { 2. Продукція харчової } \\
\text { промисловості }\end{array}$ & 6998 & 100,0 & 6918 & 100,0 & 5768 & 100,0 & 6414 & 100,0 \\
\hline Олія соняшникова & 3281 & 46,9 & 3553 & 51,4 & 3024 & 52,4 & 3705 & 57,8 \\
\hline Макуха соняшникова & 754 & 10,8 & 897 & 13,0 & 746 & 12,9 & 751 & 11,7 \\
\hline
\end{tabular}

* розраховано авторами за даними Державної служби статистики України [5]

Орієнтація на ці сім позицій є невиправданою, так як результати роботи всього агропродовольчого сектору залежать не тільки від фізичного обсягу експорту, але й динаміки експортних цін. Так, український зерновий ринок глибоко інтегрований у світовий торговельний простір у цьому сегменті та часткою більше $10 \%$ уже спроможний як впливати на кон'юнктуру світового ринку зерна, так і знаходитися під іiі впливом [2]. Збільшення виробництва зернових в світі за останні роки спричинили зниження світових цін на основні зернові культури - пшеницю, ячмінь та кукурудзу. Для українських експортерів в 2016 р. ціни у порівнянні з 2013 р. скоротились (\%): пшениці 37,8 ; ячмінь - 43,7; кукурудза - 32,8, в результаті чого при зростанні фізичного обсягу експорту валютна виручка може і зменшитися. Так, якщо в 2013 р. при реалізації 16710 тис. т кукурудзи виручка склала 3830 млн. дол., то в 2016 р. при реалізації 17286 тис. т, експортна виручка скоротилась до 2654 млн. дол. Диверсифікація експорту, збільшення кількості видів і найменувань продукції та послуг створює умови для господарського маневру, розширює можливості подолання негативного впливу на економіку несприятливої господарської кон'юнктури [4]. Диверсифікація експорту продукції рослинного походження заключається на наш погляд як шляхом збільшення виробництва і експорту інших культур - жита, вівса, зернового сорго, гречки, проса так і продукту їх переробки борошна, продукту високої доданої вартості. На світовому ринку в основному пропонується борошно пшеничне. Українські виробники та експортери борошна поки що проявляють пасивність, значно поступаючись конкурентам з Казахстану та Туреччини. 3 2012 р. світова торгівля пшеничним борошном знаходиться на підйомі і в 2015 р. оцінювалась в 13,3 млн. т. Ключовими експортерами борошна у світі є Туреччина - 2,8 млн. т, Казахстан - 1,8 млн. т і Пакистан близько 1 млн. т, на яких приходиться більше як $40 \%$ світової торгівлі [9]. Зауважимо, що Туреччина і Пакистан є постійними імпортерами пшениці, в т.ч. із
України. Україна в 2016 р. експортувала лише 369 тис. т на суму 74,3 млн. дол. Це досить скромний результат враховуючи що маючи середньорічний обсяг експорту пшениці в 2013-2016 pp. 12,4 млн. т., Україна займає шосте місце серед світових експортерів і не входить навіть в ТОП-10 великих експортерів борошна. Україна може поставити завдання зайняти провідні позиції на ринках Близького Сходу, Африки, Південної та Південно-Східної Азії враховуючи наявну виробничу базу, близько 600 борошномельних підприємств, і значні ресурси пшениці.

Аналогічна ситуація спостерігається і в олієжировому комплексі. Хоч ринок рослинних жирів в основному представлений соняшниковою, ріпаковою та соєвою оліями частка соняшникової в 2016 р. досягла 95,4 \% експортної виручки реалізації олії. В останні роки Україна є головним експортером цієї олії на світовий ринок з часткою 54-56 \% [11]. В таких умовах значно менше уваги приділяється виробництву і експорту олії із сої та ріпаку. По цих культурах основу експортної виручки складає не олія, а самі олійні культури, для переробки яких є необхідна матеріально-технічна база. На нашу думку розширення переробки цих олійних на підприємствах України значно підніме ефективність всього олієжирового комплексу, збільшить експортну виручку [1].

За період 2013-2016 рр. значно скоротився експорт готових харчових продуктів, зменшилась їх частка в продукції АПК (табл. 3).

Як видно $з$ даних табл. 3 експорт готових харчових продуктів скоротився за 2013-2016 рр. на $30 \%$ за рахунок власне продуктів харчування (позиції 1622) з 2286 млн. дол. в 2013 р. до 1146 млн. дол. в 2016 p., або на 49,9 \%. Лише по цукру та кондитерських виробах з цукру експорт зріс до 353 млн. дол., що пояснюється «проривом» цукровиків на зовнішній ринок, коли було поставлено 466 тис. т цукру на 230,4 млн. дол. Саме кондитерських виробів з цукру було експортовано на 122,6 млн. дол., що майже в два рази менше рівня $2013 \mathrm{p}$. 
Таблиця 3

Динаміка та структура експорту готових харчових продуктів за 2013-2016 рр. (за кодами 16-24 УКТЗЕД) *

\begin{tabular}{|c|c|c|c|c|c|c|c|c|c|}
\hline \multirow{3}{*}{$\begin{array}{c}\text { Код і назва товару згідно } \\
\text { УКТЗЕД }\end{array}$} & \multicolumn{8}{|c|}{ Роки } & \multirow{3}{*}{$\begin{array}{l}2016 \mathrm{p} . \\
\text { у } \% \text { до } \\
2013 \text { p. }\end{array}$} \\
\hline & \multicolumn{2}{|c|}{2013} & \multicolumn{2}{|c|}{2014} & \multicolumn{2}{|c|}{2015} & \multicolumn{2}{|c|}{2016} & \\
\hline & $\begin{array}{l}\text { млн. } \\
\text { дол. }\end{array}$ & $\%$ & $\begin{array}{l}\text { млн. } \\
\text { дол. }\end{array}$ & $\%$ & $\begin{array}{l}\text { млн. } \\
\text { дол. }\end{array}$ & $\%$ & $\begin{array}{l}\text { млн. } \\
\text { дол. }\end{array}$ & $\%$ & \\
\hline Агропродовольча продукція & 16930 & 100,0 & 16669 & 100,0 & 14563 & 100,0 & 15284 & 100,0 & 90,3 \\
\hline IV. Готові харчові продукти & 3501 & 20,7 & 3096 & 18,6 & 2468 & 16,9 & 2451 & 16,0 & 70,0 \\
\hline 16. Продукти з м'яса і риби & 43 & 0,3 & 33 & 0,2 & 12 & 0,1 & 14 & 0,1 & 32,5 \\
\hline 17. Цукор і кондвироби з цукру & 259 & 1,5 & 147 & 0,9 & 170 & 1,1 & 353 & 2,3 & 136,3 \\
\hline 18. Какао та продукти з нього & 555 & 3,3 & 323 & 1,9 & 187 & 1,3 & 162 & 1,1 & 29,2 \\
\hline 19. Готові продукти із зерна & 412 & 2,4 & 390 & 2,3 & 268 & 1,8 & 213 & 1,4 & 51,7 \\
\hline 20. Продукти переробки овочів & 404 & 2,4 & 298 & 1,8 & 184 & 1,3 & 140 & 0,9 & 34,6 \\
\hline 21. Різні харчові продукти & 251 & 1,5 & 212 & 1,3 & 117 & 0,8 & 100 & 0,6 & 39,8 \\
\hline $\begin{array}{l}\text { 22.Алкогольні та безалкогольні } \\
\text { напої, оцет }\end{array}$ & 362 & 2,1 & 251 & 1,5 & 184 & 1,3 & 164 & 1,1 & 45,3 \\
\hline $\begin{array}{l}\text { 23. Залишки і відходи харчової } \\
\text { промисловості }\end{array}$ & 922 & 5,5 & 1108 & 6,7 & 996 & 6,8 & 983 & 6,4 & 106,6 \\
\hline $\begin{array}{l}\text { 24.Тютюн і промислові замін- } \\
\text { ники тютюну }\end{array}$ & 293 & 1,7 & 334 & 2,0 & 351 & 2,4 & 322 & 2,1 & 109,9 \\
\hline
\end{tabular}

* розраховано авторами за даними Державної служби статистики України [5]

Зважаючи на світовий дефіцит цукру і підвищення якості вітчизняного цукру є можливості i надалі збільшувати обсяги експорту, освоювати нові ринки збуту. За прогнозами в 2016/2017 МР Україна спрямує іноземним споживачам понад 500 тис. т цукру [7]. По таких товарах як какао та продукти з нього, готові продукти з зерна, продукти переробки овочів, алкогольні та безалкогольні напої, різні харчові продукти серйозні втрати експортних позицій пояснюються втратою в значній мірі ринку країн СНД, куди в 2013 р. було експортовано продукції четвертої групи на суму 2239 млн. дол., що склало 62 \% загального експорту по цій групі товарів (табл. 4).

Таблиця 4

Динаміка та структура експорту агропродовольчої продукції (за кодами 1-24 УКТЗЕД) в країни СНД *

\begin{tabular}{|c|c|c|c|c|c|c|c|c|c|c|}
\hline \multirow{2}{*}{$\begin{array}{c}\text { Найменування } \\
\text { продукції }\end{array}$} & \multicolumn{2}{|c|}{2013} & \multicolumn{2}{|c|}{2014} & \multicolumn{2}{|c|}{2015} & \multicolumn{2}{|c|}{2016} & \multicolumn{2}{|c|}{$\begin{array}{l}2016 \text { р. до } \\
2013 \text { р. }\end{array}$} \\
\hline & $\begin{array}{l}\text { млн. } \\
\text { дол. }\end{array}$ & $\%$ & $\begin{array}{l}\text { млн. } \\
\text { дол. }\end{array}$ & $\%$ & $\begin{array}{l}\text { млн. } \\
\text { дол. }\end{array}$ & $\%$ & $\begin{array}{l}\text { млн. } \\
\text { дол. }\end{array}$ & $\%$ & абс. & $\%$ \\
\hline $\begin{array}{l}\text { I. Живі тварини, про- } \\
\text { дукти тваринного } \\
\text { походження }\end{array}$ & 789 & 21,8 & 516 & 21,0 & 295 & 20,3 & 206 & 18,0 & -583 & 26,1 \\
\hline $\begin{array}{l}\text { II. Продукти рослин- } \\
\text { ного походження }\end{array}$ & 331 & 9,2 & 221 & 9,0 & 107 & 7,4 & 122 & 10,6 & -209 & 36,9 \\
\hline $\begin{array}{l}\text { III. Жири та олії тва- } \\
\text { ринного або рослин- } \\
\text { ного походження }\end{array}$ & 252 & 7,0 & 150 & 6,1 & 92 & 6,3 & 73 & 6,4 & -179 & 29,0 \\
\hline $\begin{array}{l}\text { IV. Готові харчові } \\
\text { продукти }\end{array}$ & 2239 & 62,0 & 1571 & 63,9 & 960 & 66,0 & 745 & 65,0 & -1494 & 33,3 \\
\hline Всього & 3611 & 100,0 & 2458 & 100,0 & 1454 & 100,0 & 1146 & 100,0 & -2465 & 31,7 \\
\hline
\end{tabular}

* розраховано авторами за даними Державної служби статистики України [5]

Як видно 3 даних табл. 4 в складі агропродовольчої продукції найбільшу частку складають готові харчові продукти, так як це традиційний ринок для українських експортерів. Саме по цій групі товарів за період 2013-2016 рр. відбулося найбільше скорочення - 1494 млн. дол., або 68,7 \%. Головною причиною спаду в торгівлі є торгова агресія з боку Росії - традиційного і основного ринку збуту. Українські виробники втратили не тільки ринок збуту Росії, але в результаті заборони транзиту по іiі території і ринки інших держав Азії. За 2013-2016 рр. експорт готових харчових продуктів скоротився (млн. дол.): Росія 1046; Азербайджан - 68; Казахстан - 60; Туркменістан - 44; Киргизія - 46. В той же час Грузія, яка вийшла із СНД в 2016 р. імпортувала з України товарів на суму 169 млн. дол., що лише на 8 млн. дол. менше 2013. Таким чином ринок збуту товарів у країнах СНД ми поступово втрачаємо, а на європейський ринок ми ще повноцінно не увійшли, незважаючи на введення в дію асоціації з країнами СС і перешкодою 
цьому є квоти на реалізацію продукцію [10].

За короткий період українські виробники змогли частково переоріснтуватися на інші ринки i збільшити експорт готових харчових продуктів на 444 млн. дол. в значній мірі за рахунок поставок цукру, залишків і відходів харчової промисловості.

Що стосується географії експортних потоків агропродовольчої продукції то як свідчать дані тут відбуваються серйозні зміни (табл. 5).

Географічна структура експорту агропродовольчої продукції *

\begin{tabular}{|l|l|c|c|c|c|}
\hline \multirow{2}{*}{ Напрям експорту } & \multicolumn{4}{|c|}{ Роки } \\
\cline { 3 - 6 } \multirow{2}{*}{ Всього } & млн. дол. & 2013 & 2014 & 2105 & 2016 \\
\cline { 2 - 6 } & в \% & 16930 & 16669 & 14563 & 15284 \\
\hline \multirow{2}{*}{ СНД } & млн. дол. & 360,0 & 100,0 & 100,0 & 100,0 \\
\cline { 2 - 6 } & в \% & 21,3 & 2459 & 1454 & 1146 \\
\hline \multirow{2}{*}{ СС } & млн. дол. & 4485 & 14,8 & 10,0 & 7,5 \\
\cline { 2 - 6 } & в \% & 26,5 & 4753 & 4081 & 4122 \\
\hline \multirow{2}{*}{$\begin{array}{l}\text { Інші країни } \\
\text { світу }\end{array}$} & млн. дол. & 8834 & 94,5 & 28,0 & 26,4 \\
\cline { 2 - 6 } & в \% & 52,2 & 56,7 & 9028 & 10016 \\
\hline
\end{tabular}

* розраховано авторами за даними Державної служби статистики України [5]

Дані табл. 5 показують, що експорт в країни СНД поступово згортається по причині зменшення поставок в Російську Федерацію 31942 млн. дол. в 2013 р. до 93 млн. дол. в 2016 р., що вдвічі менше в порівнянні з Молдовою - 195 млн. дол. Другий по обсягу імпорту з України Європейський Союз в 2016 p. навіть збільшив закупки у порівнянні з попереднім роком на 41 млн. дол., що може бути результатом введення в дію угоди про асоціацію між Україною та ЄС. Інші країни світу - передусім країни Азії та Аф- рики вже тривалий час є головними покупцями агропродовольчої продукції з практично стабільно зростаючим з року в рік обсягом імпорту, що в 2016 р. склав 66,1 \% загального обсягу.

Важливою характеристикою експорту агропродовольчої продукції являється товарна структура в розрізі споживачів розташованих по регіонах світу. Саме вона дає можливість встановити в які країни чи об'єднання ідуть ті чи інші експортні потоки продукції (табл. 6).

Таблиця 6

Географічна та товарна структура експорту агропродовольчих товарів з України в 2016 р. *

\begin{tabular}{|c|c|c|c|c|c|c|c|c|c|c|}
\hline \multirow{3}{*}{ Регіони } & \multirow{2}{*}{\multicolumn{2}{|c|}{ Експорт, всього }} & \multicolumn{8}{|c|}{ В т.ч. } \\
\hline & & & \multicolumn{2}{|c|}{$\begin{array}{c}\text { I. Продукція } \\
\text { тваринного } \\
\text { походження } \\
\end{array}$} & \multicolumn{2}{|c|}{$\begin{array}{c}\text { II. Продукція } \\
\text { рослинного по- } \\
\text { ходження }\end{array}$} & \multicolumn{2}{|c|}{ III. Жири та олії } & \multicolumn{2}{|c|}{$\begin{array}{c}\text { IV. Готові харчові } \\
\text { продукти }\end{array}$} \\
\hline & $\begin{array}{l}\text { млн. } \\
\text { дол. }\end{array}$ & $\%$ & $\begin{array}{l}\text { млн. } \\
\text { дол. }\end{array}$ & $\%$ & $\begin{array}{l}\text { млн. } \\
\text { дол. }\end{array}$ & $\%$ & $\begin{array}{l}\text { млн. } \\
\text { дол. }\end{array}$ & $\%$ & $\begin{array}{l}\text { млн. } \\
\text { дол. }\end{array}$ & $\%$ \\
\hline СНД & 1146 & 100,0 & 206 & 18,0 & 122 & 10,6 & 73 & 6,4 & 745 & 65,0 \\
\hline EC & 4122 & 100,0 & 175 & 4,3 & 2042 & 49,5 & 1204 & 29,2 & 701 & 17,0 \\
\hline Інші & 10016 & 100,0 & 394 & 3,9 & 5931 & 59,2 & 2686 & 26,8 & 1005 & 10,1 \\
\hline Всього & 15284 & 100,0 & 775 & 5,1 & 8095 & 53,0 & 3963 & 25,9 & 2451 & 16,0 \\
\hline
\end{tabular}

Аналіз даних табл. 6 показує, що продукти рослинного походження та жири і олії в основному направляються в країни СС та інші країни, головним чином Азії та Африки. Зокрема, найбільшими імпортерами продукції рослинного походження у 2016 р. були (в \% до загального імпорту продукції АПК цих країн): Сгипет - 79,5; Іран - 65,9; Іспанія - 56,6; Туреччина - 73,5; Індонезія - 97,3. Жири та олії рослинного та тваринного походження найбільше імпортували (в \% до загального імпорту продукції АПК цих країн з України): Індія - 73,7; Китай - 51,4; Нідерланди - 45,5. Ринок готових харчових продуктів має свої особливості, а саме: це власне продукти харчування (позиції 16-22 УКТЗЕД), а також залишки і відходи харчової промисловості, тютюн і промислові замін- ники тютюну, експортні потоки яких суттєво відрізняються по регіонах. Так, країни СНД імпортують переважно продукти харчування - в 2016 р. імпорт склав 483 млн. дол. або 64,8 \% імпорту товарів четвертої групи. Країни СС імпортували переважно відходи харчової промисловості - iз імпорту готових харчових продуктів в 2016 р. в обсязі 701 млн. дол. - 439 млн. дол., або 62,6 \% склали залишки і відходи харчової промисловості, а по окремих країнах цей результат значно вищий - Нідерланди - 88,6 \%, Італія 97,3 \%, Іспанія - 88,4 \%, Франція - 99,2 \%. Аналогічна ситуація по інших країнах світу. Так, в 2016 р. із експортованих з України готових харчових продуктів на суму 1005 млн. дол., 604 млн. дол. або 60,1 \% склали відходи харчової промисловості, тютюн і 
промислові замінники тютюну - з них: Індія - $97 \%$, Туреччина - 90,3 \%, Сгипет - 72,9 \%, Марокко - 100 $\%$.

Висновки та перспективи подальших досліджень. Агропродовольча продукція в структурі загального експорту України в 2016 р. $з$ часткою $42 \%$ стає головним експортним товаром. Саме по цій продукції отримано найбільше позитивне сальдо в сумі 11394 млн. дол. Основою експорту є сім товарних позицій на які в 2016 р. приходилось 77,7 \% експортної виручки.

Обмежена номенклатура основних експортних товарів - пшениця, кукурудза, ячмінь, соя, ріпак та олія і макуха соняшникова свідчать про низький рівень товарної диверсифікації і залежність від кон'юнктури світового ринку. Незначною залишаєть- ся експорт продукції борошномельно-круп'яної промисловості і продуктів переробки сої та ріпаку.

В експортних потоках агропродовольчої продукції до країн ЄС та іншого світу переважають зернові культури та жири і олії рослинного походження, а в країни СНД - готові продукти харчування.

Тривала орієнтація експорту готових продуктів харчування (позиції 16-22 УКТЗЕД) на країни СНД виявилась хибною, що підтвердили події останніх років.

Певні зміни в структурі експорту продукції АПК можна пов'язувати зі збільшенням експорту борошна і круп, продуктів переробки сої та ріпаку, підвищенням якості продуктів харчування що дасть можливість перевести їх експортні потоки на країни ЄС та інші регіони світу.

\title{
Література
}

1. Антонюк О.П. Аналіз структури експорту агропродовольчої продукції / О.П. Антонюк, П.О. Антонюк // Економіка харчової промисловості. - 2004. - № 3(23). - С. 27-32.

2. Голомша Н.Є. Перспективи світового ринку зерна / Н.Є. Голомша, О.Я. Дзядикевич // Економіка АПК. - 2016. - № 8 - С. 49-52.

3. Гончар I.A. Характер формування зовнішньої торгівлі України: статистична оцінка I.А. Гончар, В.О. Бабірад-Лазунін // Статистика України. - 2013. - № 2. С. 16-20.

4. Гусаков В.Г. Продовольственная безопасность. Термины и понятия: энциклопедический справочник / В.Г. Гусаков. - Минск: Белоруснаука, 2008. - 356 с.

5. Державна служба статистики України [Електронний ресурс]. - Режим доступу: http: // www.ukrstat.gov.ua.

6. Карасьова Н.А. Вектори експортних потоків аграрного сектору України / Н.А. Карасьова // Економіка АПК. - 2016. - № 8. - С. 41-48. 2. - C. $26-27$.

7. Квітка Г. Ціни зростають, пардон, бо цукор рвонув за кордон / Г. Квітка // Пропозиція. - 2017. - №

8. Le commerce extérieur agricole et agroalimentaire français - principaux résultats [Електронний ресурс] - Режим доступу https://www.tresor.economie.gouv.fr/File/422039

9. Мука - продукт высокой добавленной стоимости [Електронний ресурс]. - Режим доступу: МНИАП. Рф /analytics/ Muka-produkt-vysokoj-dobavlennoj-stoimosti/

10. Мухіна І.Г. Переорієнтація економіки України на європейський ринок: реалії, ризики та перспективи / І.Г. Мухіна, О.Р. Кануннікова // Бізнес-Інформ. - 2016. - № 10. - С. 34-37.

11. Украинский рынок подсолнечного масла 2016 [Електронний ресурс] - Режим доступу: http://pelleta.com.ua/articles-rynok-podsolnechnogo-masla-2016-7.html

Стаття надійшла 26.06.2017

Стаття прийнята до друку 10.07.2017 Доступно в мережі Internet 30.09.2017

\author{
Антонюк О.П. \\ кандидат экономических наук, доцент \\ кафедра учета и аудита \\ Одесская национальная академия пищевых технологий \\ ул. Канатная, 112, г. Одеса, Украина, 65039 \\ E-mail: olegantoni@ukr.net \\ Антонюк П.0. \\ кандидат экономических наук, научный сотрудник \\ E-mail: paul antonvuk@ukr.net \\ Лысюк В.M. \\ доктор экономических наук, профессор \\ отдел рыночных механизмов и структур \\ Институт проблем рынка и экономико-экологических исследований НАН Украины \\ Французский бульвар, 29, г. Одесса, Украина, 65044 \\ E-mail: vlisyuk@ukr.net
}

\section{АНАЛИЗ ДИНАМИКИ И СТРУКТУРЫ ЭКСПОРТА АГРОПРОДОВОЛЬСТВЕННОЙ ПРОДУКЦИИ}

В статье исследуются вопросы товарной и географической структур экспорта агропродовольственной продукции, которая становится основным экспортным товаром Украины. Установлено, что 
на фоне катастрофического спада экспорта в целом, наименьшее сокращение имеет место по агропродовольственной продукции, что подтверждает высокую востребованность отечественной продукции на мировом рынке.

Выполненное исследование показывает, что в товарной структуре преобладает продукция растительного происхождения - то есть продукция с невысокой добавленной стоимостью. В то же время по продукции с высокой добавленной стоимостью имеет место значительное сокращение экспорта, что свидетельствует об ухудшении товарной структуры. В процессе анализа выяснено, что в исследуемый период основой экспорта было семь товарных позиций, на долю которых в 2016 г. пришлись 77,7 \% всего экспорта, т.е. речь идет о крайне низкой товарной диверсификации экспортных потоков агропродовольственной продукции. При насыщенности мирового рынка это привело к значительным финансовым потерям для страны в результате снижения экспортных цен. В исследовании динамики экспорта готовой пищевой продукции предложено выделить непосредственно продукты питания и остатки, отходы пищевой промышленности, а также табак и промышленные заменители табака, что позволит более объективно рассмотреть процессы динамики и структуры. Именно по продуктам питания имеет место наибольшее сокращение, что объясняется как потерей рынка в странах СНГ, так и проблемами с качеством этой продукции, в результате чего она не всегда находит покупателя на других рынках.

Анализ географической и товарной структуры экспорта позволяет установить характер основных товарных потоков: главными потребителями агропродовольственной продукции становятся страны Азии и Африки импортирующие преимущественно продукцию растительного происхождения и жиры растительного происхождения; аналогичная ситуация наблюдается с экспортом в страны ЕС, в экспорте в страны СНГ большую часть составляют готовые пищевые продукты.

На основе проведенного анализа можно сделать выводы, что Украина имеет значительный потенциал для наращивания экспорта связанный с увеличением производства и экспорта продукции мукомольно-крупяной промышленности и продукции переработки сои и рапса, повышением качества продуктов питания, что позволит выйти на рынок ЕС и других регионов мира.

Ключевые слова: агропродовольственная продукция, готовые продукты питания, товарная структура экспорта, география экспортных потоков, диверсификация экспорта, экспортная выручка.

\author{
Antonyuk 0. \\ Ph.D., Associate Professor \\ Department of Accounting and Auditing \\ Odessa National Academy of Food Technologies \\ Kanatna str., 112, Odessa, Ukraine, 65039 \\ E-mail: olegantoni@ukr.net \\ Antonyuk P. \\ $\mathrm{PhD}$, Researcher \\ Department of market mechanisms and structures \\ E-mail:paul_antonyuk@ukr.net \\ Lisyuk V. \\ Doctor of Economics, Professor \\ Department of market mechanisms and structures \\ Institute of market problems and economic \& ecological research \\ of National Academy of Sciences of Ukraine \\ Frantsuzskiy boulevard, 29, Odessa, Ukraine, 65044 \\ E-mail: vlisyuk@ukr.net
}

\title{
ANALYSIS OF DYNAMICS AND STRUCTURE OF EXPORT OF AGROFOOD PRODUCTS
}

In the article questions of a commodity and geographical structures of export of agrofood products, that becomes the basic export commodity of Ukraine has been investigated. It is found out that on the background of the catastrophic slump of export on the whole, the least reduction takes place on agrofood products that confirms high demand of home products in the world market.

The fulfilled research shows that the products of vegetable origin prevail in a commodity structure that is products with a not high surplus value. At the same time on the products with a high surplus value there is a significant reduction of export that testifies to worsening of commodity structure. It is found out in the process of the analysis, that in the investigated period seven commodity positions were the basis of export the share of which made up $77,7 \%$ of all export in 2016 , i.e. the question is about extremely low com- 
modity diversification of export streams of agrofood products. At the saturation of world market it resulted in considerable financial losses for the country as a result of decline of export prices. In the research of dynamics of export of the prepared food products it is offered to distinguish foodstuffs and bits and pieces, wastes of food industry directly, as well as tobacco and industrial substitutes of tobacco, that will allow to consider the processes of dynamics and structure more objectively. Most reduction takes place exactly on foodstuffs, that is explained by both the loss of market in the countries of the CIS and the problems concerning quality of these products, as a result they don't always find a customer on the other markets.

The analysis of regional and commodity pattern of export allows to determine the character of the basic commodity streams: the countries of Asia and Africa become the main consumers of agrofood products importing mainly the products of vegetable origin and fats of vegetable origin; an analogous situation is observed with the export in the countries of EC, in the export in the countries of the CIS the prepared food products make up the greater part.

On the basis of the conducted analysis it is possible to draw the conclusions, that Ukraine has a considerable potential for the increase of export connected with the increase of production and export of products of flour-grinding and cereals industry and products of processing of soy and rape, raising of foodstuff quality, that will allow to enter to the market of EC and other regions of the world.

Keywords: agrofood products, prepared foodstuffs, commodity structure of export, geography of export streams, diversification of export, export profit yield.

\section{References}

1. Antoniuk, O. P., \& Antoniuk, P. O. (2004). Analiz struktury eksportu ahroprodovolchoi produktsii. Ekonomika kharchovoi promyslovosti, 3(23), 27-32.

2. Holomsha, N. I., \& Dziadykevych, O. I. (2016). Perspektyvy svitovoho rynku zerna. Ekonomika APK, 8, 49-52.

3. Honchar, I. A., \& Babirad-Lazunin, V. O. (2013). Kharakter formuvannia zovnishnoi torhivli Ukrainy: statystychna otsinka. Statystyka Ukrainy, 2, 16-20.

4. Husakov , V. H. (2008). Prodovolstvennaia bezopasnost. Termynы y poniatyia: эntsyklopedycheskyi spravochnyk . Mynsk: Belorusnauka.

5. Derzhavna sluzhba statystyky Ukrainy. (n.d.). Retrieved August 23, 2017, from www.ukrstat.gov.ua.

6. Karasova , N. A. (2016). Vektory eksportnykh potokiv ahrarnoho sektoru Ukrainy . Ekonomika APK, 8, $41-48$.

7. Kvitka , H. (2017). Tsiny zrostaiut, pardon, bo tsukor rvonuv za kordon . Propozytsiia, 2, 26-27.

8. Le commerce extérieur agricole et agroalimentaire français - principaux résultats. Retrieved August 23, 2017, from www.tresor.economie.gouv.fr/File/422039

9. Muka - produkt vыsokoi dobavlennoi stoymosty. Retrieved August 23, 2017, from MNYAP. Rf /analytics/ Muka-produkt-vysokoj-dobavlennoj-stoimosti/

10. Mukhina, I. H., \& Kanunnikova, O. R. (2016). Pereoriientatsiia ekonomiky Ukrainy na yevropeiskyi rynok: realii, ryzyky ta perspektyvy . Biznes-Inform, 10, 34-37.

11. Ukraynskyi ronok podsolnechnoho masla 2016. Retrieved August 23, 2017, from http://pelleta.com.ua/articles-rynok-podsolnechnogo-masla-2016-7.html 